\title{
Height reduction in 539 tall girls treated with three different dosages of ethinyloestradiol
}

\author{
E K Normann, O Trygstad, S Larsen, K Dahl-Jørgensen
}

\begin{abstract}
During the period 1970 to 1985,539 constitutionally tall girls were treated with ethinyloestradiol in varying dosages to reduce final height. They all had a predicted final height above $181 \mathrm{~cm}(>+2 \cdot 5 \mathrm{SD})$. The girls were all healthy and were treated with three different dosages of ethinyloestradiol. Throughout these 15 years recommended treatment regimens changed, and the treatments described followed these guidelines. Girls in group 1 $(n=263)$ were treated with $0.5 \mathrm{mg}$ of ethinyloestradiol, group $2(n=178)$ with $0.25 \mathrm{mg}$, and group $3(n=98)$ with $0.1 \mathrm{mg}$. The total mean (SEM) reduction of final height was $5.9(0.2)$, $5.3(0.1)$, and $4.4(0.2) \mathrm{cm}$ when treated with $0.5,0.25$, and $0.1 \mathrm{mg}$ respectively. Group 1 was treated for $2.02(0.03)$ years and group 2 and 3 for $1.85(0.04)$ and $1.63(0.05)$ years respectively. When expressed in relation to the treatment period the reduction of final height was $3.0(0 \cdot 1), 3 \cdot 1(0 \cdot 1)$, and $2.9(0.2)$ $\mathrm{cm} /$ year of treatment respectively. All the girls were treated with ethinyloestradiol as a daily single dose, while progestogen was given daily the first $\mathbf{1 0}$ days of every month.

In conclusion we found that a daily dose of ethinyloestradiol $0 \cdot 1 \mathrm{mg}$ for about 20 months is sufficient to reduce final height. We recommend starting treatment at a bone age of about 12 years.
\end{abstract}

Tall stature is usually defined as body height of $>+2 \mathrm{SD}$ above the population mean. ${ }^{1}$ In Norway the average final height is $167 \cdot 3 \mathrm{~cm}$ in girls. According to this definition, tall stature in Norway is final height above 178.3 (SD 5.5) $\mathrm{cm} .{ }^{2}$ In 1956 Goldzieher introduced oestrogen as treatment of excessive growth in adolescent girls. $^{3}$ Since then there have been several different regimens for treating tall girls. Many investigators used conjugated oestrogens, and others used ethinyloestradiol, in varying dosages, usually combined with a progestogen 7-10 days each month to give regular vaginal bleeds. In the $1960 \mathrm{~s}$ most practitioners used $0.5 \mathrm{mg}$ of ethinyloestradiol, $0.25-0.30 \mathrm{mg}$ in the $1970 \mathrm{~s}$, and in the 1980s there have been reports indicating that $0 \cdot 1 \mathrm{mg}$ is sufficient. ${ }^{1-14}$ However, these studies include a relatively small number of patients $(n=5-100)$.

Arterial thromboembolic complications and possible carcinogenic effects of the long term oestrogen treatment by contraceptive pills make it important to find the lowest dosage of oestrogen giving a satisfactory reduction of final height. We have compared the growth reducing effect of three different dosages in 539 tall girls, demonstrating that low dose $(0.1 \mathrm{mg})$ treatment is as effective as high dose $(0.5 \mathrm{mg})$. Furthermore, we have studied the optimum age for start of treatment in relation to the treatment period needed.

\section{Patients and methods \\ PATIENTS}

During the period 1970 to 1985,1143 girls were evaluated at the outpatient clinic of the Department of Paediatrics, The National Hospital (Oslo, Norway), because of tall stature. They all went through a full physical examination. Only girls with a predicted height above $>+2.5 \mathrm{SD}$ of the normal Norwegian population, corresponding $181 \mathrm{~cm}$, were offered treatment. There were 539 of these girls; all accepted treatment and were enrolled in this study. The other girls were not followed up.

\section{METHODS}

Standing height was measured by a Holtain stadiometer and the bone age was estimated from a hand $x$ ray film according to the Greulich-Pyle radiographic atlas. ${ }^{15}$ To reduce variation the bone age was determined by one of the authors only (OT) and one experienced paediatric radiologist. If their estimates differed by more than six months the $x$ ray film was reexamined to reach agreement. The final height was predicted from the estimated bone age, according to the Bayley-Pinneau tables. ${ }^{16}$ The $x$ ray film of 11 year old girls in the radiographic atlas of Greulich-Pyle caused problems because it is more mature than the picture of 12 year old girls. To get the correct bone age it was necessary to use the film of 13-13.5 year old boys instead (156 months of age) which corresponded to 11 year old girls (132 months of age). ${ }^{17}$ Concentrations of growth hormone, prolactin, oestrogen, progesterone, follicle stimulating hormone, and luteinising hormone and activities of aspartate aminotransferase and alanine aminotranferase were measured and found normal.

The 539 girls were all treated with ethinyloestradiol (Etifollin, Nycomed). In the late 1960s and the $1970 \mathrm{~s}, 0.5 \mathrm{mg}$ of ethinyloestradiol was used as a single dose combined with norethisterone $10 \mathrm{mg}$ daily the first 10 days of every month (group $1, n=263$ ). In 1981 ethinyloestradiol was reduced to $0.25 \mathrm{mg}$ daily and norethisterone reduced to $5 \mathrm{mg}$ the first 10 days of every month (group 2, $\mathrm{n}=178$ ). In 1982 norethisterone was replaced with medroxypro- 
gesteroneacetate (MPA) $5 \mathrm{mg}$ (Perlutex, Leo) because of the androgenic effect of norethisterone as hirsutism. ${ }^{13}$ In 1983 ethinyloestradiol was further reduced to $0.1 \mathrm{mg}$ daily combined with $5 \mathrm{mg}$ of MPA the first 10 days of every month (group 3, $n=98$ ). The girls in group 1 received a total dose of $396 \mathrm{mg}$, group 2,169 $\mathrm{mg}$, and group 3, $60 \mathrm{mg}$ of ethinyloestradiol.

The girls were seen every fourth month at the outpatient clinic. They were measured, pubertal development stature was registered, and side effects noted. The bone age was estimated at six month intervals. Treatment was ended when the predicted final height was reduced to less than $180 \mathrm{~cm}$, meaning that they would not become taller than about $180 \mathrm{~cm}$ after termination of treatment. They were followed up regularly until growth had stopped.

\section{STATISTICAL METHODS}

All results are expressed as mean values with either $95 \%$ confidence interval or SEM. The confidence intervals were calculated by using Student's procedure. ${ }^{18}$ All tests were carried out two tailed and the differences considered significant when the $p$ values were less than or equal to $5 \%$. The groups were compared by two way layout analysis of variance. ${ }^{19}$

\section{Results}

The auxological data at start of treatment showed no difference in chronological age, bone age, or height at start of treatment between the three groups (table 1). The predicted heights, final heights, and the reductions of final height in the three groups are shown in table 1. The difference between the groups in reduction of final height was significant $(p<0.001)$. The duration of treatment was different in the three groups. When related to the different duration of treatment periods the height reduction was no longer significantly different between dosage regimens.

The groups were subdivided in relation to the bone age (table 2 ): $<12 \cdot 5$ years, $12 \cdot 5-13 \cdot 0$, and $\geqslant 13.0$ years. This gave us an opportunity to compare the effects of different dosages of ethinyloestradiol according to the bone age at onset of treatment. Because of the difference in treatment period between the groups it was necessary to compare the growth inhibiting effect after correction for the duration of treatment. For bone age $<12.5$ years the difference in reduction of final height between the three dosage regimens was significant $(p<0.001)$. The difference between the groups in 'corrected' height reduction ( $\mathrm{cm} /$ year of treatment) was not significant.

Table 1 Data from a study of 539 girls treated with three different dosages of ethinyloestradiol (95\% confidence interval)

\begin{tabular}{|c|c|c|c|}
\hline & $\begin{array}{l}\text { Group } 1 \\
(0.5 \mathrm{mg})\end{array}$ & $\begin{array}{l}\text { Group } 2 \\
(0.25 \mathrm{mg})\end{array}$ & $\begin{array}{l}\text { Group } 3 \\
(0.1 \mathrm{mg})\end{array}$ \\
\hline $\begin{array}{l}\text { No of patients } \\
\text { Chronological age (years) } \\
\text { Bone age (years) } \\
\text { Height at start of treatment }(\mathrm{cm}) \\
\text { Predicted height }(\mathrm{cm}) \\
\text { Final height }(\mathrm{cm}) \\
\text { Reduction of final height }(\mathrm{cm}) \\
\text { Treatment period (years) } \\
\text { 'Corrected' reduction }(\mathrm{cm} / \text { year of treatment) } \\
\text { 'Relative' reduction (mm/mg ethinyloestradiol given) }\end{array}$ & $\begin{array}{l}263 \\
13 \cdot 2(13 \cdot 0 \text { to } 13 \cdot 4) \\
12 \cdot 6(12 \cdot 5 \text { to } 12 \cdot 7) \\
175 \cdot 0(174 \cdot 4 \text { to } 175 \cdot 6) \\
185 \cdot 1(184 \cdot 7 \text { to } 185 \cdot 5) \\
179 \cdot 2(178 \cdot 8 \text { to } 179 \cdot 6) \\
5 \cdot 9(5 \cdot 5 \text { to } 6 \cdot 3) \\
2 \cdot 02(1 \cdot 96 \text { to } 2 \cdot 08) \\
3 \cdot 0(2 \cdot 8 \text { to } 3 \cdot 2) \\
0 \cdot 16\end{array}$ & $\begin{array}{l}178 \\
13 \cdot 1(12 \cdot 9 \text { to } 13 \cdot 3) \\
12 \cdot 6(12 \cdot 5 \text { to } 12 \cdot 7) \\
175 \cdot 4(174 \cdot 8 \text { to } 176 \cdot 0) \\
185 \cdot 5(185 \cdot 1 \text { to } 185 \cdot 9) \\
180 \cdot 2(179 \cdot 8 \text { to } 180 \cdot 6) \\
5 \cdot 3(5 \cdot 1 \text { to } 5 \cdot 5) \\
1 \cdot 85(1 \cdot 77 \text { to } 1 \cdot 93) \\
3 \cdot 1(2 \cdot 9 \text { to } 3 \cdot 3) \\
0 \cdot 31\end{array}$ & $\begin{array}{l}98 \\
13 \cdot 8(13 \cdot 6 \text { to } 14 \cdot 0) \\
12 \cdot 7(12 \cdot 6 \text { to } 12 \cdot 8) \\
174 \cdot 2(173 \cdot 6 \text { to } 174 \cdot 8) \\
183 \cdot 1(182 \cdot 7 \text { to } 183 \cdot 5) \\
178 \cdot 7(178 \cdot 3 \text { to } 179 \cdot 1) \\
4 \cdot 4(4 \cdot 0 \text { to } 4 \cdot 8) \\
1.63(1 \cdot 53 \text { to } 1 \cdot 73) \\
2 \cdot 9(2 \cdot 5 \text { to } 3 \cdot 3) \\
0 \cdot 73\end{array}$ \\
\hline
\end{tabular}

Table 2 Data of 539 girls treated with ethinyloestradiol, divided according to bone age (95\% confidence interval)

\begin{tabular}{|c|c|c|c|}
\hline & \multicolumn{3}{|l|}{ Bone age (years) } \\
\hline & $<12 \cdot 5$ & $12 \cdot 5-13 \cdot 0$ & $\geqslant 13 \cdot 0$ \\
\hline $\begin{array}{l}\text { No of girls } \\
\text { Chronological age (years) } \\
\text { Height at start of treatment }(\mathrm{cm}) \\
\text { Predicted height }(\mathrm{cm}) \\
\text { Final height }(\mathrm{cm}) \\
\text { Reduction of final height }(\mathrm{cm}) \\
\text { Treatment period (years) } \\
\text { 'Corrected' reduction (cm/year) }\end{array}$ & $\begin{array}{l}104 \\
12 \cdot 3(12 \cdot 1 \text { to } 12 \cdot 5) \\
171 \cdot 8(171 \cdot 0 \text { to } 172 \cdot 6) \\
185 \cdot 8(185 \cdot 2 \text { to } 186 \cdot 4) \\
178 \cdot 2(177 \cdot 6 \text { to } 178 \cdot 8) \\
7 \cdot 6(7 \cdot 2 \text { to } 8 \cdot 0) \\
2 \cdot 15(2 \cdot 03 \text { to } 2 \cdot 27) \\
3 \cdot 8(3 \cdot 6 \text { to } 4 \cdot 0)\end{array}$ & $\begin{array}{l}72 \\
13 \cdot 3(13 \cdot 1 \text { to } 13 \cdot 5) \\
175 \cdot 5(174 \cdot 9 \text { to } 176 \cdot 1) \\
185 \cdot 5(184 \cdot 9 \text { to } 186 \cdot 1) \\
179 \cdot 5(178 \cdot 9 \text { to } 180 \cdot 1) \\
6 \cdot 0(5 \cdot 4 \text { to } 6 \cdot 4) \\
2 \cdot 06(1 \cdot 96 \text { to } 2 \cdot 16) \\
3 \cdot 0(2 \cdot 8 \text { to } 3 \cdot 2)\end{array}$ & $\begin{array}{l}87 \\
14 \cdot 2(14 \cdot 0 \text { to } 14 \cdot 4) \\
178 \cdot 3(177 \cdot 7 \text { to } 178 \cdot 9) \\
183 \cdot 9(183 \cdot 3 \text { to } 184 \cdot 5) \\
180 \cdot 2(179 \cdot 6 \text { to } 180 \cdot 8) \\
3 \cdot 7(3 \cdot 5 \text { to } 3 \cdot 9) \\
1 \cdot 81(1 \cdot 74 \text { to } 18 \cdot 9) \\
2 \cdot 2(2 \cdot 0 \text { to } 2 \cdot 4)\end{array}$ \\
\hline $\begin{array}{l}\text { No of girls } \\
\text { Chronological age (years) } \\
\text { Height at start of treatment }(\mathrm{cm}) \\
\text { Predicted height }(\mathrm{cm}) \\
\text { Final height }(\mathrm{cm}) \\
\text { Reduction of final height (cm) } \\
\text { Treatment period (years) } \\
\text { 'Corrected' reduction (cm/year) }\end{array}$ & $\begin{array}{l}47 \\
12 \cdot 3(12 \cdot 1 \text { to } 12 \cdot 5) \\
172 \cdot 4(171 \cdot 4 \text { to } 173 \cdot 4) \\
186 \cdot 1(185.4 \text { to } 186 \cdot 9) \\
179 \cdot 5(178 \cdot 7 \text { to } 180 \cdot 3) \\
6.6(6.0 \text { to } 7 \cdot 2) \\
1.96(1.80 \text { to } 2 \cdot 12) \\
3.6(3.2 \text { to } 4 \cdot 0)\end{array}$ & $\begin{array}{l}91 \\
13 \cdot 2(13 \cdot 0 \text { to } 13 \cdot 4) \\
175 \cdot 6(175 \cdot 0 \text { to } 176 \cdot 2) \\
185 \cdot 5(184 \cdot 9 \text { to } 186 \cdot 1) \\
180 \cdot 2(179 \cdot 8 \text { to } 180 \cdot 6) \\
5 \cdot 3(4 \cdot 9 \text { to } 5 \cdot 7) \\
1.90(1 \cdot 78 \text { to } 2 \cdot 02) \\
3 \cdot 1(2 \cdot 9 \text { to } 3 \cdot 3)\end{array}$ & $\begin{array}{l}40 \\
13 \cdot 9(13 \cdot 7 \text { to } 14 \cdot 1) \\
178 \cdot 7(177 \cdot 7 \text { to } 179 \cdot 7) \\
184 \cdot 8(183.8 \text { to } 185 \cdot 8) \\
181 \cdot 3(180 \cdot 3 \text { to } 182 \cdot 3) \\
3 \cdot 7(3 \cdot 3 \text { to } 4 \cdot 1) \\
1 \cdot 61(1 \cdot 45 \text { to } 1 \cdot 77) \\
2 \cdot 5(2 \cdot 1 \text { to } 2 \cdot 9)\end{array}$ \\
\hline $\begin{array}{l}\text { No of girls } \\
\text { Chronological age (years) } \\
\text { Height at start of treatment (cm) } \\
\text { Predicted height }(\mathrm{cm}) \\
\text { Final height (cm) } \\
\text { Reduction of final height (cm) } \\
\text { Treatment period (years) } \\
\text { 'Corrected' reduction (cm/year) }\end{array}$ & 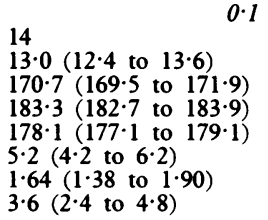 & $\begin{array}{l}52 \\
13 \cdot 7(13.5 \text { to } 13.9) \\
173.9(173.5 \text { to } 174 \cdot 3) \\
183 \cdot 3(182 \cdot 9 \text { to } 183 \cdot 7) \\
178 \cdot 3(178 \cdot 9 \text { to } 179 \cdot 7) \\
4.9(4 \cdot 5 \text { to } 5 \cdot 3) \\
1.67(1.55 \text { to } 1 \cdot 79) \\
3.3(2.9 \text { to } 3 \cdot 7)\end{array}$ & $\begin{array}{l}32 \\
14 \cdot 2(13 \cdot 8 \text { to } 14 \cdot 6) \\
176 \cdot 2(175 \cdot 4 \text { to } 177 \cdot 0) \\
182 \cdot 5(181 \cdot 9 \text { to } 183 \cdot 1) \\
179 \cdot 4(178 \cdot 8 \text { to } 180 \cdot 0) \\
3 \cdot 1(2 \cdot 5 \text { to } 3 \cdot 7) \\
1 \cdot 58(1 \cdot 36 \text { to } 1 \cdot 80) \\
2 \cdot 1(1 \cdot 7 \text { to } 2 \cdot 5)\end{array}$ \\
\hline
\end{tabular}




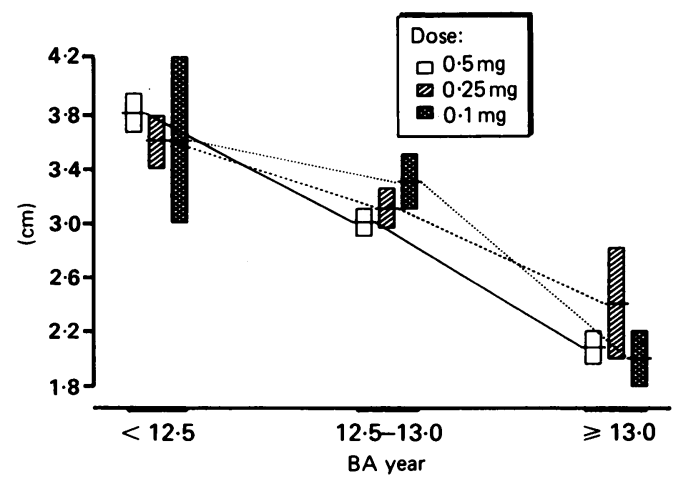

Reduction of final height (cm/year of treatment) in constitutionally tall girls treated with three different dosages of ethinyloestradiol, divided into groups depending on bone age $(B A)$ in years. Bars indicate mean with $95 \%$ confidence interval.

In the group with bone age $12 \cdot 5-13 \cdot 0$ years the height reduction was significantly different between the three dosage regimens $(p<0.01)$, but there was no significant difference between the groups in 'corrected' reduction.

In the most mature group (bone age $\geqslant 13.0$ ) there was no significant difference between the three dosage regimens in either total or 'corrected' height reduction (fig 1).

In none of these groups did the girls develop side effects that lasted more than three months. The main side effect was nausea. Some had dysmenorrhea, but usually this disappeared after some months. A detailed report on side effects was published earlier and showed fewer problems with low dose treatment. ${ }^{13}$ The girls were not followed up systematically after completion of treatment. Some have become mothers and, as far as we know, none has developed infertility problems or malignant disease. This is too early to ascertain breast and genital carcinomas. No girl has developed prolactinoma to our knowledge.

\section{Discussion}

In 1975 Zachmann et al reported a study of 40 girls treated with a daily dosage of $0.3 \mathrm{mg}$ of ethinyloestradiol. ${ }^{20}$ The average reduction of final height was $4.6 \mathrm{~cm}$. The reduction in the youngest group with bone age $12 \cdot 1-13$ years was $5.8 \mathrm{~cm}$ while the reduction in the group with bone age $13 \cdot 1-14$ years was $4 \cdot 0 \mathrm{~cm}$. The group with bone age $14 \cdot 1-15$ had a reduction of $4.5 \mathrm{~cm}$. The differences were not significant, but they gave an indication that the reduction of final height was less when treatment was started after bone age of about 13 years. This corresponded to the study of Kuhn et al reported in $1977 .^{21}$ They presented a study with 17 girls treated with $0.5 \mathrm{mg}$ daily of ethinyloestradiol. The reduction of final height was significantly greater when treatment was started before a bone age of 12 years. The mean reduction was $8.9 \mathrm{~cm}$ when bone age was less than 12 years and $5.5 \mathrm{~cm}$ when between 12 and 13 years. There was not a statistical difference in reduction before compared with after menarche $(6.4 v$ $5.7 \mathrm{~cm}$ respectively). In 1978 Bierich reported a study of 41 girls treated with $7 \cdot 5 \mathrm{mg}$ of conjugated oestrogen daily. ${ }^{5}$ The average height reduction was $7 \cdot 3 \mathrm{~cm}$, but $8.3 \mathrm{~cm}$ when treated before menarche (mean bone age 11.8 years) and $6.8 \mathrm{~cm}$ when treated after menarche (mean bone age 12.9 years).

Also in 1978 Crawford reviewed different oestrogen regimens. ${ }^{7}$ They all showed height reductions between 3.5 and $7.3 \mathrm{~cm}$. However, he did not discuss whether high or low dose regimens gave different results. In 1989 Grüters et al reported one of the first studies where the reduction of final height in different dosage regimens was compared. ${ }^{9}$ They showed that the reduction of final height was $4.9 \mathrm{~cm}$ in the low dose $(0 \cdot 1 \mathrm{mg}$ of ethinyloestradiol daily) compared with $5.1 \mathrm{~cm}$ in the high dose $(0 \cdot 3-0.5 \mathrm{mg}$ daily) regimen. This difference was not significant. The final height was reduced when treatment was started at a bone age less than 13 years. The groups were small ( $n=44$ and $n=38$ respectively) and they were treated at two different centres.

These results are all in accordance with ours. There is no statistical difference in growth inhibiting effect between the three dosages when the duration of treatment and bone age at start of treatment are taken into account. Using $0.1 \mathrm{mg}$ of ethinyloestradiol is as efficient as 0.5 mg. It has been suggested that in girls with more advanced pubertal development, a higher dosage of oestrogen should be more effective. ${ }^{12}$ In girls with bone age $\geqslant 13.0$ years the total height reduction was $6 \mathrm{~mm}$ less when given $0 \cdot 1$ $\mathrm{mg}$ daily compared with the $0.5 \mathrm{mg}$ regimen, but when correlated to the treatment period there was no difference. This does not justify a higher dosage $(0.5 \mathrm{mg})$ which would, with a treatment period of 2.02 years, be equivalent to a total dose of about 36 years' use of a low dose (35 $\mu \mathrm{g}$ ) contraceptive pill compared with six years when treated with $0.1 \mathrm{mg}$ ethinyloestradiol daily for 1.63 years. Thus irrespective of the bone age when starting treatment, low dose oestrogen treatment is as effective as high dose treatment. Furthermore early treatment, starting before bone age 12.5 years, is most effective. After bone age 13 years less benefit is obtained. There is a definite decrease in growth reducing effect when bone age is $\geqslant 13.0$ years. The difference in reduction of final height between the two groups with bone age less than 13 years is clinically not significant, although it is statistically different due to the large number of patients.

This is the first report including more than 500 tall girls from only one centre examined and treated by the same investigator. This minimises the variations observed in height measurements, bone age estimations, height predictions, and indications of treatment.

From our study we conclude that starting treatment at a bone age of about $12 \cdot 0-12 \cdot 5$ years, using $0.1 \mathrm{mg}$ of ethinyloestradiol daily for about two years, combined with $5 \mathrm{mg}$ medroxyprogesteroneacetate daily for the first 10 days of every month, will give satisfactory results with an average reduction of final height of $5 \cdot 2 \mathrm{~cm}$. Because of the possibility of nausea, with or without vomiting, we recommend starting treatment on a Friday to minimise loss of schooling. Such side effects are most frequent with higher 
dosages. As Trygstad reported in 1986, there has not been a problem of major side effects. ${ }^{13}$ Whether even lower dosages (for example 35 $\mu \mathrm{g}$ daily) are equally effective should be assessed in a prospective clinical trial.

1 Bailey JD, Park E, Cowell C. Estrogen treatment of girls with constitutional tall stature. Pediatr Clin North Am 1981;28: 501-12.

2 Brundtland GH, Liestøl K, Walløe L. Height and weight of school children and adolescent girls and boys in Oslo 1970. Acta Paediatr Scand 1975;64:565-73.

3 Goldzieher MA. Treatment of excessive growth in the adolescent female. F Clin Endocrinol Metab 1956;16:249-52.

4 Bartsch O, Weschke B, Weber B. Oestrogen treatment of constitutionally tall girls with $0 \cdot 1 \mathrm{mg} /$ day ethinyloestradiol. Eur F Pediatr 1988;147:59-63.

5 Bierch JR. Estrogen treatment of girls with constitutional tall Bierch JR. Estrogen treatment of girls

6 Conte FA, Grumbach MM. Estrogen use in children and adolescents: a survey. Pediatrics 1978;62:1091-7.

7 Crawford JD. Treatment of tall girls with estrogen. Pediatric 978;62:1189-95

8 Greenblatt RB, McDonough PG, Mahesh VB. Estrogen therapy in inhibition of growth. Fournal of Clinical Endo crinology 1966;26:1185-91.

9 Grüters A, Heidemann P, Schlüter H, Stubbe P, Weber B Helge $\mathbf{H}$. Effect of different oestrogen doses on final heigh reduction in girls with constitutional tall stature. Eur f Pediatr 1989;149:11-3.
10 Hindmarsh PC, Brook CGD. Tall stature, In: Brook CGD, ed. Clinical paediatric endocrinology. 2nd Ed. Oxford: ed. Clinical paediatric endocrinology. 2nd Ed.

11 Prader A, Zachmann $M$. Treatment of excessively tall girls and boys with sex hormones. Pediatrics 1978;62:1202-10.

12 Schamback H, Nitschke U. Die Behandlung des konstitutionellen Hochwuchses bei Mädchen mit physiologischen Östrogendosen in der Präpubertät. Monatsschr Kinderheilkd 1985;133:32-7.

13 Trygstad $O$. Oestrogen treatment of adolescent tall girls; short term side effects. Acta Endocrinol (Copenh) (Suppl) 1986;279:170-3.

14 Wettenhall HNB. The tall child. In: Brook CGD, ed. Clinical paediatric endocrinology. Oxford: Blackwell Scientific Publications, 1981:134-40.

15 Greulich WW, Pyle SI. Radiographic atlas of skeletal development of the hand and wrist. 2nd Ed. Stanford: Stanford University Press, 1959.

16 Bayley N, Pinneau SR. Tables for predicting adult height from skeletal age: revised for use with the Greulich-Pyle rom skeletal age: revised for use with the Greulich-Pyle

17 Pyle SI, Waterhouse AM, Greulich WW. Radiographic standard of reference for the growing hand and wrist. Chicago: Press of Case Western Reserve Ur

18 Kendall $M$, Stuart A. The advanced theory of statistics. 2nd Ed. London: Charles Griffin, 1979.

19 Kendall M, Stuart A, Ord JK. The advanced theory of statistics. 3rd Ed. London: Charles Griffin, 1983.

20 Zachmann M, Ferrandez A, Mürset G, Prader A. Estrogen treatment of excessively tall girls. Helvetica Paediatrica Acto 1975;30:11-30.

21 Kuhn N, Blunck W, Stahnke J, Wiebel J, Willig RP. Estrogen reatment in tall girls. Acta Paediatr Scand 1977;66:161-7. 